\title{
Nina Rodrigues e A loucura epidêmica de Canudos
}

\author{
Ana Maria Galdini Raimundo Oda
}

Sobre o autor e sua obra

Raimundo Nina Rodrigues (1862-1906) - médico maranhense que radicou-se na Bahia - tem seu nome associado à constituição de três campos de saber, no Brasil: a antropologia, a medicina legal e a psiquiatria. Em seu breve tempo de vida escreveu e publicou muito, e seus principais estudos visaram: registrar a cultura dos africanos escravizados e de seus descendentes no Brasil; definir as relações supostas entre raça/alienação mental, raça/crime e degeneração/ crime; e teorizar sobre a psicologia coletiva, partindo de casos brasileiros que chamou de "loucuras epidêmicas".

Partindo da premissa de que haveria "uma reação patológica diferente para os diversos tipos antropológicos de que se compõe a população deste país" (Nina Rodrigues, 1939, p. 193), ele se propôs a estudar essas diferenças, de acordo com os parâmetros científicos da época. Um dos problemas apontados por ele, para a adequada consecução destes estudos, era justamente a precariedade dos critérios definidores de raça no Brasil, falha que pretendeu sanar em suas pesquisas. Acreditava ainda que as três raças 
fundamentais (negros, índios e brancos) "transmitem aos produtos de seus cruzamentos caracteres patológicos diferenciais de valor" (idem, p. 203), sendo a competente diferenciação das raças muito importante para a prática médica, tanto para as doenças físicas como para as mentais.

Observe-se que a definição de Nina Rodrigues de transmissão hereditária era anterior aos conceitos da genética clássica que hoje permeiam nosso cotidiano ${ }^{1}$. Ele trabalhava com as seguintes noções: as características adquiridas seriam transmitidas aos descendentes; o cruzamento de raças muito diferentes implicaria sempre degeneração física e mental dos descendentes, e essa degeneração poderia se acentuar por influências externas, do ambiente; o mestiços seriam produtos híbridos tanto fisicamente quanto em suas manifestações intelectuais e culturais; entre os degenerados, os instintos atávicos, primitivos, poderiam ressurgir de acordo com as condições ambientais.

Para melhor entender o autor em pauta é preciso recordar que, no fim do século XIX, o conceito de degeneração ou degenerescência era corrente na medicina mental, especialmente entre os autores franceses e italianos, referenciais teóricos de Nina Rodrigues. Tal teoria foi sistematizada por Bénédict Augustin Morel (1809-1873), no Tratado das degenerescências, de 1857, onde a degenerescência se definia como desvio de um tipo primitivo perfeito, desvio este transmissível hereditariamente. Mais tarde, a partir de 1870, Valentin Magnan (1835-1916) retomou Morel, mas redefiniu a idéia de degenerescência à luz do evolucionismo, considerando-a um estado patológico, em que o desequilíbrio físico e mental do indivíduo degenerado interromperia o progresso natural da espécie; certos tipos específicos de loucura estariam associados à degenerescência - todo degenerado seria um desequilibrado mental, mas nem todo louco seria degenerado; tal degenerescência poderia ser herdada ou adquirida, manifestando-se em sinais, chamados estigmas, físicos, intelectuais e comportamentais (Ackerknecht, 1964; Bercherie, 1989; Serpa Jr., 1998). A teoria da degenerescência, na vertente sintetizada por Magnan, influenciou muito os estudos médico-psiquiátricos de Nina Rodrigues; outra referência sua, o psiquiatra italiano Cesare Lombroso (1836-1909) partiu também de Magnan para criar uma antropologia criminal, muito popular no fim do século XIX, que relacionava degeneração e criminalidade (Ackerknecht, 1964), e cujas teorias Nina Rodrigues procurou testar empiricamente no Brasil.

1. Em fins do século XIX, houve um notável avanço da citologia: em 1883, Auguste Weismann distinguiu as células em duas linhagens, a somática e a germinativa, única responsável pela transmissão hereditária de caracteres - acabou aqui a crença na transmissão das qualidades adquiridas; em 1900, as "leis de Mendel" foram redescobertas e postas em circulação junto aos novos conhecimentos da biologia - no início do século XX, delimitou-se o campo da genética clássica (Serpa Jr., 1998). Nina Rodrigues não viveu para incorporar esses novos conceitos. 
Com relação ao estudo do que chamava de "coletividades anormais" e "loucuras epidêmicas" brasileiras, Nina Rodrigues estabeleceu um debate com os fundadores do campo - florescente na época - denominado psicologia coletiva ou psicologia das multidões, tais como, entre outros, Scipio Sighele e Gustave Le Bon. Sua principal crítica a estes autores era não terem dado, a seu ver, o devido valor à influência que a loucura teria no funcionamento das multidões; procurou demonstrar esta influência em seus estudos de casos nacionais, baseando-se sobretudo nos trabalhos sobre a loucura a dois e o contágio mental de Lasègue e Falret e de Marandon de Motyel, e sobre a natureza histérica das manifestações coletivas de loucura, segundo Charcot e sua escola (Nina Rodrigues, 1939).

Por fim, não podemos deixar de fazer referência, ainda que breve, aos estudos antropológicos de Nina Rodrigues, que coletou minuciosamente o depoimento dos últimos africanos na Bahia para estudar a procedência, as línguas, as religiões e os costumes originais e os seus desdobramentos nas práticas religiosas e sociais de seus descendentes brasileiros, como os terreiros de candomblé, por exemplo (Nina Rodrigues, 1932/1982 e 1900/1935).

Norteando a escolha de seus variados objetos de estudo (a cultura negra, o alienado, o criminoso, as loucuras coletivas), evidencia-se uma tentativa de definição da identidade brasileira, preocupação explícita nos textos de Nina Rodrigues e correspondente, na área médica, a um movimento intelectual mais amplo, nas últimas décadas do século XIX e início do século XX. Seu espírito investigativo era genuíno e o levava a dialogar constantemente com seus colegas brasileiros e com os mestres europeus, em publicações nacionais e em periódicos franceses e italianos. Neste sentido, pode-se dizer que Nina Rodrigues procurou fazer uma psiquiatria brasileira que tivesse em conta um certo caráter nacional, mesmo filiando-se a escolas européias.

\section{Sobre 0 artigo}

"A loucura epidêmica de Canudos" foi publicado originalmente na Revista Brasileira, em novembro de 1897 (ano III, tomo XII), aparecendo no ano seguinte em francês, nos Annales Médico-Psychologiques de Paris (1898, maio-junho). Em 1939, Artur Ramos o republica, junto a outros cinco artigos esparsos de Nina Rodrigues, no volume As coletividades anormais, de onde o transcrevemos agora.

$\mathrm{O}$ artigo foi escrito pouco antes do término da batalha final de Canudos - como s infere da nota acrescentada por Nina Rodrigues ao primeiro parágrafo - sendo, portanto, do ponto de vista historiográfico, um relato contemporâneo, quase imultâneo aos fatos ocorridos. Não nos cabe aqui examinar se a versão dos fatos lescrita pelo autor é exata em seus detalhes, nem se sua interpretação do contexto 
social e político em que se deu o fenômeno Canudos seria a mais apropriada ${ }^{2}$. $\mathrm{O}$ certo é que Nina Rodrigues, em sua análise conjuntural, nos mostra a sua visão de médico, membro da elite intelectual da época, defensor da república e conhecedor das grandes diferenças existentes entre o mundo rural dos sertões nordestinos e aquele das grandes capitais brasileiras, supostamente europeizadas.

Neste artigo, Nina Rodrigues articula as noções, citadas acima, de raça, degenerescência, atavismo e suas relaçōes com as loucuras individual e coletiva, dentro de um contexto específico que lhes dá cores próprias.

Inicia com a descrição da loucura de Antonio Maciel, classificando seu caso como delírio crônico de Magnan, o equivalente à psicose sistemática progressiva de Garnier. Para o diagnóstico do delírio crônico, Nina Rodrigues utiliza a longa evolução do quadro mental, seguindo Magnan, que em suas Leçons Cliniques (1893) descreve quatro fases: a fase inicial inespecífica, uma fase de incubação, com inquietação, nervosismo, busca de explicações para os sofrimentos próprios em causas externas, em que começam as alucinações auditivas; a segunda fase, em que o delírio se coordena e se estrutura, as alucinações se intensificam, a personalidade se altera e se dissocia, há luta contra os sintomas persecutórios e disso decorre debilitação física; na terceira fase, a megalomaníaca, a desagregação mental propicia o aparecimento de idéias de grandeza, a seguir, o delírio de perseguição se atenua, a inteligência enfraquece, preparando a quarta fase, a demência, caracterizada pela indiferença e confusão mental (Bercherie, 1989).

Também como Magnan, Nina Rodrigues considera que é a estrutura geral do quadro que define o diagnóstico, não seus conteúdos, variáveis com a educação, o meio social e a época em que vive o alienado (Bercherie, 1989). A loucura religiosa de Antonio Conselheiro toma tal forma por ser ele mestiço, filho do sertão e com a religiosidade própria deste (medieval, diz Nina Rodrigues), e ele reage aos fatos externos de grande repercussão, como o fim da monarquia, incorporando o atual ao delírio inicial, reformulando-o.

2. Entre os historiadores há divergências quanto aos fatos materiais, por exemplo, quanto ao número de seguidores de Conselheiro e de soldados das tropas do governo, nos sucessivos confrontos travados durante 1896-1897; sobre as condições de fortificação da vila no confronto final; sobre o número total de mortos de ambos os lados etc. Menos ainda se estabelece um sentido único quanto à análise do significado político das lutas que lá se travaram; basta lembrar que a historiografia oficial, da época e mesmo atual, chama o ocorrido de revolta ou guerra de Canudos, enfatizando a desobediência civil de rebelados monarquistas e a ameaça à república nascente; autores mais críticos o denominam massacre de Canudos, enfatizando o caráter fortemente repressivo dessa atuação do exército brasileiro, um grande genocídio; Antonio Conselheiro já foi descrito como louco, fanático religioso e como revolucionário; o estilo de vida e a organização social dos habitantes do povoado de Belo Monte é alvo de controvérsias etc. 
Nina Rodrigues considerava, a princípio, Conselheiro "realmente muito suspeito de ser degenerado, na sua qualidade de mestiço" (Nina Rodrigues, 1939, p. 133); pouco depois do fim dos conflitos, examinou o seu crânio, observando que se tratava de uma peça normal, sem sinais de degeneração. Acresceu a isto os dados que pôde recolher da história pessoal do alienado: este "descendia de uma família cearense valente e belicosa (...)" e de onde proviriam "as tendências, o temperamento belicoso que a loucura pôs em relevo em Antonio Conselheiro" (idem, p. 134). Concluiu, pois, não se tratar de um degenerado, o que confirmaria o diagnóstico de delírio crônico, que segundo Magnan acometeria os "predispostos simples", indivíduos considerados normais até a eclosão da doença mental (Serpa Jr., 1998).

A seguir, a teoria do contágio vesânico na loucura a dois, de Lasègue e Falret (1877), é transposta para a situação brasileira, e coloca Antonio Conselheiro como o elemento ativo, o íncubo, e a massa que o seguia como o elemento passivo, os súcubos.

Para justificar o grau de influência sugestiva alcançado neste caso de contágio, o autor descreve, de um lado, uma organização social primitiva (muito aquém do que considerava o ápice do progresso, a civilização do homem branco europeu), composta por indivíduos mestiços de negros, índios e brancos, os jagunços, seres híbridos em que o caráter bárbaro da fração selvagem de seus ascendentes (negros e índios) se encontraria mal refreada, pronta para se manifestar violentamente. Em outro artigo, de 1901, Nina Rodrigues admite que entre os seguidores de Conselheiro não haveria apenas indivíduos fanáticos, realmente alienados, mas também outros apenas convencidos ou supersticiosos, outros bandidos e criminosos. Em cada tipo, a influência delirante repercutiria segundo o seu temperamento e as suas predisposiçôes (Nina Rodrigues, 1939).

De outro lado, ressalta, há um momento histórico conturbado, a passagem da monarquia à república, a conseqüente separação da igreja e Estado e uma crise econômica que deixariam inseguros e insatisfeitos os habitantes do sertão. Vê ele neste contexto o terreno ideal para o desenvolvimento de uma epidemia de loucura, combustível a que um louco poderia atear fogo.

Mas não haveria de ser qualquer louco, e sim um louco profeta, mestiço como a massa que o seguia. A mestiçagem traria a predisposição à alienação mental, a sugestionabilidade e o desequilíbrio mental necessários ao contágio vesânico e daria (quase literalmente) a cor brasileira aos fenômenos que os estudiosos da psicologia das multidões tinham descrito na Europa.

\section{Referências bibliográficas}

ACKERKNECHT, E.H. (1964). "El problema de la degeneración". In Breve historia de la psiquiatría. $2^{\mathrm{a}}$ ed. Buenos Aires: Universitária, pp. 37-41. 


$$
\begin{aligned}
& R \text { E V I S T A } \\
& \text { LATINOAMERICANA } \\
& \text { DE PSICOPATOLOGIA } \\
& \text { FUNDAMENTAL }
\end{aligned}
$$

BERCHERIE, P. (1989). "Magnan". In Os fundamentos da clínica: história e estrutura do saber psiquiátrico. Rio de Janeiro: Zahar, pp. 149-160.

Nina Rodrigues, R. (1939). "A loucura epidêmica de Canudos". In As coletividades anormais. Organização, prefácio e notas de Artur Ramos. Rio de Janeiro: Civilização Brasileira, pp. 50-77.

(1939). "Os mestiços brasileiros". Op. cit., pp. 195-205.

(1939). "A loucura das multidões - nova contribuição ao estudo das loucuras epidêmicas no Brasil". Op. cit., pp. 78-152.

(1935). O animismo fetichista dos negros baianos. Prefácio e notas de Artur Ramos. Rio de Janeiro: Civilização Brasileira (originalmente publicado em 1900, em francês).

(1982). Os africanos no Brasil. 6ª ed. Organização e prefácio de Homero Pires. São Paulo: Ed. Nacional (originalmente publicado em 1932).

SERPA JR., O.D. (1998). "Genes: do colar de pérolas ao ADN". In Mal-estar na naturezaestudo crítico sobre o reducionismo biológico em psiquiatria. Rio de Janeiro: Te Corá, pp. 168-178.

(1998). "Os destinos da teoria da degenerescência". Op. cit., pp. 137-150. 


\title{
A loucura epidêmica de Canudos Antonio Conselheiro e os jagunços*
}

\author{
Nina Rodrigues
}

Para a narração fiel dos sucessos de Canudos forçosamente estará obrigado o historiador a aguardar o termo das lutas que ali se pelejam atualmente. ${ }^{\prime}$

Os antecedentes daquela situação, a estratificação social e étnica em que a loucura de Antonio Maciel cavou os fundos alicerces do seu poderio material e espiritual quase indestrutível, desde já abremse ao contrário de par em par em franco acesso a todas as investigações científicas.

* Publicado originalmente em Nina Rodrigues, As coletividades anormais (organização, prefácio e notas de Artur Ramos), Rio de Janeiro, 1939, pp. 50-77.

1. Não altera de uma linha as consideraçōes deste estudo a notícia que nos acaba de transmitir o telégrafo de que, a 5 de outubro, o general Arthur Oscar, que desde junho se achava em Canudos à frente de mais de 12 mil homens, apoderou-se finalmente daquele reduto, batendo completamente o bando de fanáticos que ali seachavam entrincheirados.

Foi encontrado o cadáver de Antonio Conselheiro, já sepultado no santuário de uma igreja que ali estava construído, com tais proporções que se havia transformado em uma fortaleza inexpugnável. A conducta de Antonio Conselheiro, mantendo-se até à morte no seu posto, quando the teria sido facílimo retirar-se de Canudos para ponto mais estratégico, é a confirmação final da sua loucura na execução integral do papel do Bom Jesus Conselheiro, que lhe havia imposto a transformação de personalidade do seu delírio crônico. (Este trabalho foi publicado em 1 de novembro de 1897 na Revista Brasileira, ano III, fasc. 69. A.R.) 
No entanto, as três fases que tem atravessado a história de Antonio Conselheiro coincidem rigorosamente com os três períodos admitidos na marcha da psicose primitiva.

A vida de Antonio Maciel até a sua internação na Bahia, tal como a conta o Sr. João Brigido, do Ceará, constitui o primeiro período. Antonio Conselheiro é natural de Quixeramobim, no Estado do Ceará, e chama-se Antonio Vicente Mendes Maciel. Seu pai, que havia sido proprietário e negociante abastado, legou-lhe com o encargo de três irmãs solteiras, a direção de uma casa comercial pouco consolidada. Casadas as irmãs, por sua vez Antonio Maciel toma estado desposando uma prima. "O casamento de Antonio Maciel - diz um informante - foi um desastre. Pouco tempo depois vivia na mais infrene desinteligência com a sogra, por isso que açulava a filha a maltratá-lo". Nesta situação, Antonio Maciel fez ponto no seu comércio, liquidando os seus negócios. Em 1859 mudou-se de Quixeramobim para Sobral, onde foi caixeiro de um negociante, daí passou-se a Campo Grande, onde por algum tempo exerceu o cargo de escrivão de juiz de paz. Mudou-se ainda para a vila do Ipú, onde um sargento de polícia raptou-lhe a mulher. Retirou-se imediatamente para a cidade do Crato, e desta para os sertões da Bahia. Contam que em caminho para o Crato, ao passar em Paus Brancos, foi acometido de um acesso de loucura em que feriu um seu cunhado, em cuja casa se achava hospedado.

Dissenções contínuas com a mulher e com a sogra, mudanças sucessivas de emprego e de lugar, revolta agressiva com vias de fato e ferimento de um parente que o hospeda, não é preciso mais para reconhecer os primeiros esboços da organização do delírio crônico sob a forma do delírio de perseguição. A fase inicial da sua loucura, o período de inquietação, de análise subjetiva, ou de loucura hipocondríaca, em rigor nos escapa na história de Antonio Maciel à míngua de um conhecimento mais íntimo de sua vida no lar. É, porém, fácil perceber a influência das alucinações e a procura da fórmula do seu delírio no que sabemos das suas lutas conjugais e, sobretudo, nessas mudanças repetidas. Por tal forma característica dos delirantes crônicos é este modo de reação que Favila crismou de alienados migradores, aqueles que as repetidas e sucessivas mudanças pedem de balde um refúgio, uma proteção contra a implacável perseguição que lhes movem as próprias alucinações, das quais nada os poderá libertar senão libertando-os da mísera mente enferma.

Penetrando nos sertões da Bahia, para o ano de 1876, Antonio Maciel levava finalmente descoberta a fórmula do seu delírio. O batismo de Antonio Conselheiro, pelo qual o ministro ou enviado de Deus inicia a sua carreira de missionário e propagandista da fé, era o atrio apenas de onde a loucura religiosa o havia de elevar ao Bom Jesus Conselheiro, da frase megalomaníaca da sua psicose.

Antonio Conselheiro, revestido, a modo dos monjes, com longa túnica azul cingida de grossa corda, descalço, arrimado a tosco bordão, empreende missões ou 
desobrigas copiadas das que nos sertões realizam todos os anos, por religiosos de todas as ordens sacras, e que diferem tanto do que devia ser uma verdadeira prática cristã quando achava Alimena ${ }^{3}$ que "un vechio volume ascético pieno di figure di diavoli e di dannati differisce del profumato e rico libro di preghiere di uma bela signora, quanto le prediche melodrammatiche di un missionário differiscono delle conferenze spirituali del padre Agostino de Montefeltro."

Pregando contra o luxo, contra os maçons, fazendo queimar nas estradas todos os objetos que não pudessem convir a uma vida rigorosamente ascética, Antonio Conselheiro anormaliza extraordinariamente a vida pacífica das populações agrícola e criadora da província, distraindo-as das suas ocupações habituais para uma vida errante e de comunismo em que os mais abastados cediam parte dos seus recursos em favor dos menos protegidos da fortuna.

Bem aceito por alguns vigários, em luta aberta com outros, no fim de alguns meses de propaganda Antonio Conselheiro é preso e enviado para o Ceará, sob suspeita de ter sido criminoso na sua província natal. Já por essa ocasião, em pleno segundo período, bem se revelava a coerência lógica do delírio na transformação da personalidade do alienado. A turba que seguia Antonio Conselheiro quis opôr-se à sua prisão, mas, à semelhança de Cristo, ordena-lhes Conselheiro, que não se movam, e entrega-se à guarda, afirmando aos discípulos que iria mas havia de voltar um dia. Imperturbável a serenidade com que se comportou então. Fatos bastante significativos sāo referidos por testemunhas do interrogatório que aí sofreu.

$\grave{A}$ autoridade que lhe inqueria dele para fazê-los punir, quais dos guardas o haviam maltratado fisicamente em viagem, limitou-se Antonio Conselheiro a responder que mais do que ele havia sofrido o Cristo. E por única resposta às múltiplas perguntas sobre a sua conduta, sobre seus atos retorquiu com uma espécie de sentença evangélica que "apenas se ocupava em apanhar pedras pelas estradas para edificar igrejas".

Verificado no Ceará que Antonio Conselheiro não era criminoso, e posto em liberdade imediatamente, regressou ao seio das suas ovelhas, coincidindo precisamente, segundo crença geral, o dia que de repente aí surgiu com aquele que havia marcado para a sua reaparição. E cada vez mais encarnado no papel de enviado de Deus, desde então Antonio Conselheiro prosseguiu imperturbável nas suas missões, até o advento da República, em 1889.

Este acontecimento político devia influir poderosamente para incrementar o prestígio de Antonio Conselheiro, levando-o ao terceiro período da psicose progressiva. Veio ele desdobrar o delírio religioso do alienado, salientando o fundo de perseguição que, tendo-lhe acompanhado sempre, como é de regra na sua psicose,

3. Alimena: I limiti e i modificatori della imputabilitá. Vol. 1, 1894, p. 23, 
como reação contra os maçons e outros inimigos da religião, por essa ocasião melhor se concretizou na reação contra a nova forma de governo em que não podia ver se não um feito dos seus naturais adversários. As grandes reformas promulgadas pela república nascente, tais como separação da Igreja do Estado, secularização dos cemitérios, casamento civil etc., estavam talhadas de molde a justificar essa identificação.

Personificado no governo republicano o adversário a combater, Antonio Conselheiro declarou-se monarquista. Nas regiões onde ele predominava continuaram a prevalecer as leis e os atos do tempo da monarquia. Recusou-se a receber moeda que tivesse dizeres da República, só tendo curso como valiosa a que trazia a efŕgie do monarca deposto; aconselhou francamente que não se pagasse impostos ao governo republicano e nem consentia que se tivessem por válidos os atos do estado civil que não fossem realizados de acordo com as leis religiosas. Secundado pela luta que o clero católico do país abriu contra essas reformas, amparado pelas crenças monárquicas e religiosas da população sertaneja, o prestígio de Antonio Conselheiro atingiu o apogeu. $\mathrm{O}$ atestado da sua atividade nesse prazo e da força da convicção religiosa que despertava esta escrito ao vivo pelas paróquias do interior deste Estado, nos inúmeros cemitérios, capelas e igrejas que nelas edificou. $\mathrm{O}$ rebanho de fiéis que o acompanhava, e para o qual a fé cega na sua santidade já era dogma incontrovertível, contou com milhares de pessoas.

E derramada a fama dos seus milagres pelos infindos sertões dos Estados do Norte e do Centro do país acorreram, dos pontos mais remotos, em contínuas e intermináveis caravanas, multidões de crentes e devotos, a ouvir a palavra inspirada do profeta, a buscar a desobrigação dos seus pecados, a receber na fase tormentosa e agitada porque está passando o País a senha da conduta e dos flagícios que melhor abrandem e desarmem a cólera divina provocada pela ingratidão usada com o velho monarca decaído, e que lhes haja de grangear pelo menos a felicidade celeste, já que na terra vai perdida a esperança de reavê-la.

A coerência do seu delírio se demonstra na correção com que desempenha o papel de enviado de Deus. A sua vida, em que o desprezo das preocupaçōes mundanas o levam a prescindir de todos os cuidados higiênicos do corpo, se prende o menos possível à contingência dos mortais. Antonio Conselheiro não dorme, não come ou quase não come. O seu viver é uma oração contínua e contínuo o seu convívio com Deus, provavelmente de origem alucinatória.

São todos acordes em confessar que, na população que o seguia, jamais consentiu ou patrocinou desmandos ou atentados contra a propriedade ou contra pessoas.

À insubordinação contra o governo civil seguiu-se a revolta contra os poderes eclesiásticos. Foi, ainda, o reconhecimento do governo pelo clero que mais acentuou as desinteligências em que Antonio Conselheiro se tinha visto envolvido com alguns 
vigários no começo das suas missões. Depois disso, Antonio Conselheiro tinha chegado a viver de perfeita harmonia com os párocos de algumas freguesias. Mas, em seguida ao reconhecimento da República, foi-se estabelecendo de novo profundo desacordo entre eles. Conta-se que, tendo-lhe alguém objetado que tanto não era maçônico o governo republicano que o Papa tinha aconselhado o clero francês a reconhecê-lo, Antonio Conselheiro declarou que, se o Papa tinha de fato dado semelhante conselho, este tinha andado mal. Por último, o crisma tornou-se franco e não pôde mais haver acordo possível entre ele e as autoridades eclesiásticas.

Tentou-se, nestes últimos anos, uma missão de catequese entre os adetos de Antonio Conselheiro. Mas os frades capuchinhos a que fora cometida essa missa, apesar da recepção, se não de todo hostil pelo menos reservada do Conselheiro, tiveram de fugir diante da atitude ameaçadora dos discípulos e da turba do profeta, declarando formalmente ao regressar que só a intervenção armada dos poderes civis poderia por bom termo àquela anomalia.

Parece que aquilo que a catequese de tempos idos obteve do índio feroz e canibal, no recesso das matas virgens do Novo Mundo, na ignorância completa dos costumes, da língua do aborígene a quem mais irritavam e tornavam ferozes as perseguições cruéis do conquistador, a catequese dos tempos que correm não pôde conseguir de uma população naturalmente inclinada à generosidade e à religião. E é tarefa mais fácil e expedita destruir os recalcitrantes à bala do que convertê-los pela lenta persuasão religiosa. No entanto, a necessidade de chamar a grande massa de povo que o seguia à obediência das leis da República, que nem ele nem os seus sequazes queriam admitir, fez prever desde logo a todo o mundo que a luta havia de passar forçosamente da simples propaganda pela palavra para o terreno da ação pelas armas.

Em seguida a diversos insucessos de pequenas expedições policiais, Antonio Conselheiro deixou a vila de Bom Jesus, quase edificada por ele e internando-se pelo sertão foi estabelecer o quartel general da propaganda em Canudos, reduto de difícil acesso e que em curto prazo ele havia transformado de estância deserta e abandonada em uma vila florescente e rica.

Quando a necessidade obrigou a tornar efetiva a obediência à lei, Antonio Conselheiro achava-se admiravelmente aparelhado para a resistência, pela natureza do local ocupado. As conseqüencias dessa luta são conhecidas.

Sucessivamente três expedições militares, cada qual mais poderosa, têm naufragado em Canudos, inflingindo ao exército brasileiro dolorosas perdas e lamentáveis revezes. Cem praças comandadas pelo alferes Pires Ferreira foram destroçadas em Uauá; cerca de quinhentos soldados da expedição do major Febronio de Brito foram batidos na serra do Cambáio e tiveram de efetuar uma retirada perigosíssima. Cerca de 1.500 homens da expedição comandada pelo coronel Moreira Cézar foram destroçados em Canudos, sucumbindo o chefe da expedição. Hoje o 
exército brasileiro em peso bate-se já há três meses em Canudos, os hospitais regorgitam de feridos, é elevado o número de oficiais mortos, e não se sabe ao certo quando terminará a luta.

Alguma coisa mais do que a simples loucura de um homem era necessária para este resultado e essa alguma coisa é a psicologia da época e do meio em que a loucura de Antonio Conselheiro achou combustível para atear o incêndio de uma verdadeira epidemia vesânica.

As leis que regem a manifestação epidêmica da loucura são precisamente as mesmas que Lasègue e Falret formularam desde 1877 para o caso mais simples do contágio vesânico, o caso do delírio a dois.

Três momentos básicos reconhecem essas leis.

Em primeiro lugar, a existência de um elemento ativo que era o delírio e o impõe à multidão que passa a representar o elemento passivo do contágio ${ }^{4}$. Embora aceitando as idéias delirantes, a multidão reage por seu turno sobre o elemento ativo, retificando, emendando, coordenando o delírio que só então se torna comum.

Em segundo lugar, é indispensável uma convivência prolongada das duas ordens de espíritos, "vivendo uma vida comum, no mesmo meio, partilhando o mesmo modo de interesses, os mesmos temores, as mesmas esperanças e estranhos a qualquer outra influência exterior".

Em terceiro e último lugar, o contágio do delírio requer nele "um caráter de verossimilhança à sua manutenção nos limites do possível, repousando em fatos ocorridos no passado ou em temores e esperanças concebidas para o futuro".

Em Canudos, representa de elemento passivo o jagunço que corrigindo a loucura mística de Antonio Conselheiro e dando-lhe umas tinturas das questões políticas e sociais do momento, criou, tornou plausível e deu objeto ao conteúdo do delírio, tornando-o capaz de fazer vibrar a nota étnica dos instintos guerreiros, atávicos, mal extintos ou apenas sofreados no meio social híbrido dos nossos sertões, de que o louco como os contagiados são fiéis e legítimas criações. Ali se achavam de fato, admiravelmente realizadas, todas as condições para uma constituição epidêmica de loucura.

O jagunço é um produto tanto mestiço no físico, que reproduz os caracteres antropológicos combinados das raças de que provém, quanto híbrido nas suas manifestações sociais, que representam a fusão inviável de civilizações muito desiguais.

Pelo lado etnológico, não é jagunço todo e qualquer mestiço brasileiro. Representa-o em rigor o mestiço do sertão, que soube acomodar as qualidades viris

4. Em rigor no elemento passivo do contágio vesânico a loucura é toda superficial e sem raízes. Para fazê-la desaparecer de todo, bastava retirar os indivíduos do ambiente sugestivo em que se achavam. 
dos seus ascendentes selvagens, índios ou negros, às condições sociais da vida livre e da civilização rudimentar dos centros que habita. Muito diferente é o mestiço do litoral, que a aguardente, o ambiente das cidades, a luta pela vida mais intelectual do que física, uma civilização superior às exigências da sua organização física e mental, enfraqueceram, abastardaram, acentuando a nota degenerativa que já resulta do simples cruzamento de raças antropologicamente muito diferentes, e criando, numa regra geral que conhece muitas exceções, esses tipos imprestáveis e sem virilidade que vão desde os degenerados inferiores, verdadeiros produtos patológicos, até esses talentos tão fáceis, superficiais e palavrosos quanto abúlicos e improdutivos, nos quais os lampejos de uma inteligência vivaz e de curto vôo correm parelhas com a falta de energia e até de perfeito equilíbrio moral.

No jagunço, ao contrário, revelam-se inteiriços o caráter indomável do índio selvagem, o gosto pela vida errante e nômade, a resistência aos sofrimentos físicos, à fome, à sede, às intempéries, decidido pendor pelas aventuras da guerra, cuja improvisação eles descobrem no menor pretexto, sempre prontos e decididos para as razias das vilas e povoados, para as depredaçōes à mão armada, para as correrias de todo o gênero que os interesses do mando, as exigências da politicagem e as ambições de aventureiros fazem suceder-se de contínuo por toda a vasta extensão das zonas pouco habitadas do país.

Seria desconhecer o nosso próprio país acreditar que nessas vastas regiões seja mais do que nominal a existência da civilização européia. O que ali impera é um compromisso entre as tendências para uma organização feudal por parte da burguesia abastada e a luta das represálias de tribos bárbaras ou selvagens por parte da massa popular.

Todas as grandes instituições que na civilização deste fim de século garantem a liberdade individual e dão o cunho da igualdade dos cidadãos perante a lei, sejam políticas como o direito do voto, o governo municipal autônomo etc., sejam judiciárias como o funcionamento regular dos tribunais, tudo isso é mal compreendido, sofismado e anulado nessas longínquas paragens. O que predomina soberana é a vontade, são os sentimentos ou os interesses pessoais dos chefes, régulos ou mandões, diante dos quais as maiores garantias da liberdade individual, todas as formas regulares de processo, ou se transformam em recurso de perseguição contra inocentes, se desafetos, ou se anulam em benefício de criminosos, quando amigos. E a mais das vezes, a execução dessa vontade soberana é sumaríssima, e em nada diferem os processos escolhidos do que eram os adotados pelo selvagem que antes do europeu possuiu este país.

Antigamente eram estes senhores feudais os grandes estancieiros, os criadores abastados, os proprietários de engenho; atualmente são principalmente os chefes políticos locais, os amigos do governo, os fabricantes de eleitores fantásticos. 
A luta entre os que estão de posse do poder e os que disputam essa posse, admiravelmente favorecida nos tempos monárquicos pelo revesamento no governo dos dois partidos constitucionais, mas então como ainda hoje melhor favorecida ainda pelas intrigas e arranjos das camarilhas que cercam os governos centrais, sempre trouxe dividida a população sertaneja em dois grupos opostos e rivais, em dois campos inimigos e irreconciliáveis, capitaneados por verdadeiros régulos, de que os jagunços representavam apenas o exército, a força material.

Esta situação que o jagunço não chega mesmo a compreender, mas de que acaba sempre sendo o responsável legal, oferece-lhes todavia o melhor ensejo para satisfação dos seus instintos guerreiros.

Foi sempre nessas lutas, políticas ou pessoais, que se revelaram todas as qualidades atávicas do mestiço. Dedicado até a morte, matando ou deixando-se matar sem mesmo saber por que, foi sempre inexcedível o valor com que se batiam, consumada a tática, a habilidade de guerrilheiros que punham em prática, relembrando as lutas heróicas do aborígine contra o invasor europeu.

Essas qualidades que tão grande realce dão hoje às guerras que se pelejam em Canudos, não são, pois, peculiares às tropas de Antonio Conselheiro; são características do jagunço.

Como Vila-Nova, como João Abbade, era jagunço Gumercindo Saraiva, o terrível cabo de guerra que dos pampas do Rio Grande, à frente das suas hostes veio bater às portas de São Paulo; é jagunço Montalvão, o destemido general das guerrilhas de Andaraí e o foram os Araújos e Maciéis, do Ceará, os Ledos e Leões, do Grajaú, no Maranhão, e um pouco por toda parte, todos os guerrilheiros dos sertões do Brasil inteiro.

Belicamente, Canudos é, pois, um caso apenas, e mais nada, dos ataques de Xique-Xique, Andaraí, Cochó, Brejo-Grande, Lençóis, Belmonte, Canavieiras etc., neste Estado; de Carolina, Grajaú, no Maranhão; de mil outras localidades de Goiás, Pernambuco, Minas Gerais etc.

Mas para que bem se possa compreender a importância que neste elemento belicoso devia tornar o caso de Canudos, é preciso atender a que era Canudos na época da primeira luta pelejada no Brasil em nome das convicções monárquicas que são as convicções do sertanejo.

Para acreditar que pudesse ser outro o sentimento político do sertanejo, era preciso negar a evolução política e admitir que os povos mais atrasados e incultos podem, sem maior preparo, compreender, aceitar e praticar as formas de governo mais liberais e complicadas.

A população sertaneja é e será monarquista por muito tempo, porque no estágio inferior da evolução social em que se acha, falece-lhe a precisa capacidade mental para compreender e aceitar a substituição do representante concreto do poder pela abstração que ele encarna, pela lei. Ela carece instintivamente de um rei, de um chefe, 
de um homem que a dirija, que a conduza, e por muito tempo ainda o presidente da República, os presidentes dos Estados, os chefes políticos locais serão o seu rei, como, na sua inferioridade religiosa, o sacerdote e as imagens continuam a ser os seus deuses. Serão monarquistas como são fetichistas, menos por ignorância, do que por um desenvolvimento intelectual, ético e religioso, insuficiente ou incompleto.

$\mathrm{O}$ que é pueril é exigir que essas populações compreendam que a federação republicana é a condição, a garantia da futura unidade política de um vasto País em que forçosamente hão de concorrer povos, muito diferentes de índole, de costumes e de necessidade, o que requer uma elasticidade de ação que não poderia oferecer a centralização governamental da monarquia.

O que não se pode exigir delas é que reconheçam que as dificuldades do momento são a conseqüência lógica e natural dos ensaios, tentativas e experiências de adaptação do povo que procura a orientação toda pessoal que mais lhe há de convir na nova organização política. Para essa população, o raciocínio não pode ir além da comparação da situação material do País antes e depois da República. A monarquia era os viveres baratos, a vida fácil; a república é a vida difícil, a carestia dos gêneros alimentícios, o câmbio a zero.

Por seu turno, não é peculiar a Canudos a tendência a se constituir em uma epidemia vesânica de caráter religioso.

Se os estudos que tenho publicado sobre a religiosidade fetichista da população baian $\mathrm{a}^{5}$ não ministrassem já documentos suficientes para se julgar da crise em que se encontra o seu sentimento religioso no conflito entre a imposição pela educação que recebe a população, de um ensinamento religioso superior à sua capacidade mental, e a tendência para as concepções religiosas inferiores que requer a sua real capacidade efetiva, nós poderíamos corroborá-las com a prova do que neste momento se passa nesta cidade com relação à interna epidemia de varíola que desapiedadamente a flagela. Por menos observador que seja o espírito, por mais que o disfarce o lixo que cobre as ruas da cidade, não é possível percorrê-la sem notar a singularidade de haver em cada canto de rua milho estalado ao fogo, de mistura com azeite de dendê. Em um só dia que as exigências da clínica me fizeram percorrer grande parte da zona mais vitimada pela varíola, tive ensejo de contar vinte e tantos desses estranhos depósitos feitos da noite precedente.

Prende-se este fato a uma crença fetichista africana profundamente enraizada na nossa população. A erupção variólica representa para ela apenas uma manifestação da possessão pelo orixá Xapanã, Omobu ou Obaluaê.

5. Veja $O$ animismo fetichista dos negros bahianos na Revista de 15 de abril, 1 de maio, 15 de junho, 1 e 15 de julho, 1 de agosto e 4 de setembro de 1896. (Reeditado na Biblioteca de Divulgação Cientifica, vol. II, A.R.) 
Decorrem desta concepção crenças populares que se transformam em obstáculos insuperáveis à aplicação regular das medidas sanitárias profiláticas. A população de cor despreza a vacina porque está convicta de que o melhor meio de abrandar a cólera do orixá é fazer-lhe sacrifícios que consistem em lançar nos cantos das ruas em que ele habita a sua iguaria favorita - milho estalado em azeite de dendê.

Muitos acreditam que trazendo milho assim preparado nos bolsos ou debaixo do leito estão suficientemente preservados. E pior do que tudo isso é a convicção imposta pelo rito iorubano, de que o santo ou orixá exige que, longe de fugir, todos se aproximem dele.

Não é mais complicada a terapêutica que deriva crenças. Basta dar ao doente o que é preciso para alimentar o santo, farinha de milho e azeite de dendê. Dizem que as negras chegam a untar o corpo dos seus doentes com o azeite divino. Referiram-me, como prova da eficácia da terapêutica animista, que na convalescença de uma varíola confluente grave, a filhinha de um médico mestiço descia do leito e ingeria impunemente a farofa de milho e azeite de dendê deposta debaixo da cama em oferta a Xapanã.

Ora, se na população da capital têm curso práticas e doutrinas desta natureza, pode-se prever o que há de ser a religião dos sertanejos. Para esta população, as abstrações religiosas são fortes demais. A necessidade de uma divindade tangível e material se impöe com força suficiente para destruir todo o prestígio de uma crença cuja história ela aprendeu de cor, mas que transcendente demais, não lhe pode criar a emoção do sentimento religioso.

A chacun des degrés de leur évolution, escreveu Spencer, ${ }^{6}$ les hommes doivent penser avec les idées qu'is possèdent. Tous les changements Qui attirent leur attention et dont ils peuvent observer les origines ont des hommes et des animaux pour antécédents; par suite, ils sont incapables de se figurer les antécédents en général sous d'autres formes, et ils donnent ces formes aux puissances créatrices. Si l'on veut alors leur enlever ces conceptions concrètes, pour leur donner à la place des conceptions comparativent abstraites, leur esprit n'aura plus de conceptions du tout, puisque ces conceptions nouvelles me pourront être representées dans l'entendement. Il aura été de même à chaque époque de l'histoire des croyances religieuses, depuis la première jusqu'à la dernière.

Alimento a suposição de ter demonstrado com fatos que a população brasileira é puramente fetichista, ainda mesmo na afirmação das suas crenças católicas.

A divinização de Antonio Conselheiro devia, pois, dar plena satisfação às necessidades do seu sentimento religioso. Era a satisfação do seu fetichismo instintivo

6. Spencer. Les premiers principes. Paris, 1888, p. 37. 
dentro da educação religiosa cristã que essa população recebe desde o berço, embora sem poder assimilá-la suficientemente.

Explica-se assim a facilidade com que Antonio Conselheiro suplantou o prestígio do clero católico. Mas antes de Antonio Conselheiro este prestígio já tinha sido invariavelmente suplantado todas as vezes que o clero teve de combater uma tournure fetichista mais escandalosa dada pela população a práticas do culto católico.

Já demonstramos uma vez ${ }^{7}$ a ineficácia das condenações do clero como recurso contra uma verdadeira romaria fetichista a Santo Antonio da Barra, aqui nesta capital.

Igualmente ineficazes foram as medidas repressivas empregadas para obstar que a população continuasse a afluir aos atos divinos realizados na igreja interdita de Nossa Senhora das Candéias e por um sacerdote suspenso de ordens. De todos esses exemplos, porém, o mais grave é o do padre Cícero, em Joazeiro no Ceará. Eis como o descrevo em um artigo sob o título expressivo de - Contumácia, a Cidade do Salvador, conceituado orgão católico desta cidade:

O povo diz que vê a sagrada hóstia desfazer-se em sangue na boca da beata, e jura que Deus faz sentir o seu poder e a sua misericórdia naquelas paragens. Bandos e bandos de peregrinos de todas as circunvizinhanças abandonaram os seus lares e correram à eclesiástica, examina maduramente a questão, aprecia-a sob todas as faces, estuda com atenção, e depois de aturado exame, resolve que o fato que tanto ruído fizera, não passa de uma farsa, de um ardil, que é preciso desmascarar. Grandes são os trabalhos, enormes os esforços do diocesano para fazer calar no ânimo daquele povo crédulo e exaltado a falsa persuasão do milagre. Segue a Roma a questão, é confirmado o veredicto do bispo da Diocese. Recolhe-se a uma casa religiosa a beata, suspende-se o padre que se torna costumes no seu erro, proíbe-se a crença do fato milagroso. Mas o povo continua a crer no seu milagre; o padre suspenso continua a residir na mesma localidade e em seus arredores; é considerado uma vítima de insidiosa intolerância: e tudo isto serve de fermento para novos inconvenientes. E aqui está um sacerdote, obrigado a acatar e respeitar a voz da Igreja, a zelar e defender a inteireza de sua doutrina, a obedecer e submeter-se às determinações de seus superiores hierárquicos, a ser a pedra de escândalo de uma paróquia, quiçá do Brasil inteiro, o cabeça de uma revolta funesta e fatal, o provocador de um crisma latente e perigoso, que se não for sopitado e abafado, virá a trazer dias de amarguras para a santa Igreja e para a Pátria brasileira.

Nesta população de espírito infantil e inculto, assim atormentada por uma aspiração religiosa não satisfeita, forçosamente havia de fazer profunda sensação a figura impressionante de um problema ou enviado divino desempenhada por um delirante crônico na fase megalomaníaca da psicose.

7. Illusões de catechese no Brasil, Revista de 15 de março de 1897. (Publicado como o último capítulo de $O$ animismo fetichista dos negros bahianos. A.R.) 


\section{CLÁSSICOS DA PSICOPATOLOGIA}

Tous ces malades sont fiers, dignes et magesteux dans leur atitude, escreve Régis, et ils ne départent pas un seul instant de leur serieux et de leur solemnité. On dirait les acteurs de tragédie chargés de quelque rôle royal qui continueraient en public et dans le costume de leur emploie à jouer leurs personages.

Tal é a origem e a explicação da força sugestiva do Conselheiro no papel de elemento ativo da epidemia de loucura de Canudos.

Mas foi o instinto belicoso, herdado por essa população do indígena americano, que, para dar satisfação pelas armas às suas aspirações monarquistas, se apoderou do conteúdo do delírio de perseguição de Conselheiro que, nas suas concepções vesânicas tinha acabado identificando a República com a maçonaria.

E foi este o segredo da bravura e da dedicação fanatizada dos jagunços que, de fato, se batiam pelo seu rei e pela sua fé. 